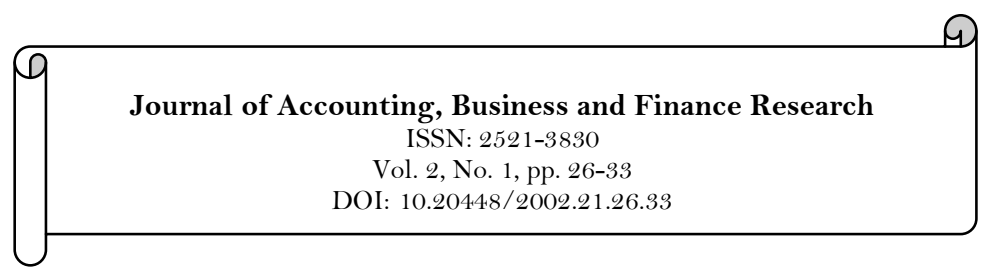

\title{
A Multivariate Analysis of Determinants of Profitability: Evidence from Selected Manufacturing Companies Listed on the Ghana Stock Exchange
}

\author{
Kwadwo Boateng Prempeh ${ }^{1}$ \\ Allan McBright Sekyere ${ }^{2}$ \\ Eric Kwame Amponsah Addy ${ }^{2}$ \\ 1,2,s Department of Accountancy, Sunyani Technical University, Ghana. \\ Email:_baprempeh2002@yahoo.co.uk
}

\begin{tabular}{l|l}
\multicolumn{3}{c}{ Abstract } & \\
This study seeks to examine the determinants of profitability of & Keywords: \\
manufacturing companies in Ghana. The study covered the period & $\begin{array}{l}\text { Profitability } \\
\text { Manufacturing companies } \\
\text { 2005- } 015 \text { using data gathered from five selected manufacturing } \\
\text { companies listed on the Ghana Stock Exchange (GSE). The Study }\end{array}$ \\
employed the Multivariate Regression Analysis Technique. Return \\
on Assets, a measure of profitability, was used as the dependent \\
on
\end{tabular}

\section{Introduction}

Profit is considered as one of the most important objectives of any business entity that management of every business strives to achieve in addition to secondary objectives such as increasing market share and increasing sales volume. Profit can serve as an indicator of the level of efficiency of a business. A high profit is an indication that a business is efficiently utilizing its funds (Aparna, 2015). A company's ability to increase its profit, to survive and be competitive is more of an issue nowadays due to market liberalization (Yazdanfar, 2013). Profitability is the ability of a company to earn profit from all of its operations. Profit is the earnings from sales or revenue after all costs, including interest payment on debt and tax have been deducted (Bashar \& Islam, 2014).

Over the last decade, a number of significant changes have occurred in the Ghanaian manufacturing sector as a result of trade liberalization, internationalization of competition (especially from the Asian countries), and the relatively high cost of production as compared to other countries. The manufacturing sector in Ghana has performed relatively poorly since 2007 with the sector recording negative growth for the years 2007, 2009, 2013 and 2014 with growth rates of $-1.2 \%,-1.3 \%,-0.5 \%$ and $-0.8 \%$ respectively. The highest growth rate for the period between 2007 and 2016 was recorded in 2011 with a growth rate of $17 \%$. The average growth rate for the period is $3.14 \%$ (Ghana Statistical Service, 2017). The manufacturing sector plays an important role in the development of any country, and Ghana, being a developing country that imports more products than it exports, it is vital for the country to develop its manufacturing sector. The survival of any company depends on its ability to be profitable. The profitability of the manufacturing companies is therefore, crucial for their survival. 
It is common knowledge that the determinants of profitability of manufacturing companies is essential for their survival, thus, enhancing the economic development of the country which is adopting an export-oriented industrialization within an open economic policy (Pratheepan, 2014). While there exists extensive literature examining the profitability of the manufacturing sector in developed countries, empirical work on determinants of profitability of manufacturing companies in developing economies like Ghana is relatively scarce. Ghana is an import-based economy, hence, little attention is paid to scholarly works in the manufacturing sector (Prempeh, Sekyere, \& Asare, 2016). The purpose of this study is therefore, to examine the determinant of profitability of manufacturing companies listed on the Ghana stock exchange.

\section{Literature Review}

Related literature on determinants of profitability for different types of industries is in abundance. However, most of it produced different results. Sufian and Chong (2008) examined the determinants of Philippine Banks' profitability for the period 1990- 2005 using a multivariate regression analysis model. The findings suggested that size, credit risk, and expense preference behavior are negatively related to Banks' profitability, while non-interest income and capitalization have a positive effect. Economic growth, money supply and stock market capitalization did not significantly explain the variation in the profitability of Philippine Banks'. However, Al-Jafari and Al Samman (2015) investigated the profitability for industrial Firms in Oman using the ordinary least square (OLS) regression model for the period 2006 to 2013 . Results from the study revealed that there is a significant positive relationship between profitability, firm size, growth, fixed assets and working capital, but a negative significant relationship between profitability, and financial leverage. Pratheepan (2014) examined the determinants of profitability for Sri Lankan manufacturing companies for the period 2003- 2012 using the ordinary least square. The results of the study indicate that there is a significant positive relationship between profitability and firm size. Although there was a negative relationship between leverage and profitability, the relationship was not statistically significant. Aparna (2015) did an analysis on the determinants of profitability of Steel Authority of India (SAIL) using the ordinary least square regression analysis technique. The results from the analysis showed that there is a negative relationship between firm size, leverage and productivity which were not consistent with the findings of Al-Jafari and Al Samman (2015) which showed a positive relationship between firm size and profitability. Maroa and Kioko (2016) in their study investigating the determinants of profitability of Agricultural Firms in Kenya, used multiple regression techniques which covered the period of 2006-2014. The study revealed that there is a positive significant relationship between liquidity, firm size and profitability while tangibility has a significant negative relationship with profitability.

In Nigeria, Tobi, Osidero, and Kareem (2016) examined the relationship between liquidity and profitability of manufacturing firms using OLS regression. It was observed that liquidity and profitability were inversely related in food and beverage, Healthcare and Breweries sub-sectors respectively while a positive relationship was observed between liquidity and profitability in the conglomerate, building material and chemical sub-sectors. A study conducted by Sivathaasan, Tharanika, Sinthuja, and Hanitha (2013) investigated whether factors such as capital structure, working capital, firm size, non-debt tax shield and growth rate have any impact on the profitability of manufacturing companies in Sri Lanka employing the multiple regression technique. The results of the study revealed that there is a significant relationship between capital structure, non-tax shield and profitability. The remaining variables, (i.e. working capital, growth rate and firm size) have no significant relationship with profitability. Zaid, Wan Muhd, and Zulqernain (2014) examined the determinants of profitability on construction companies in Malaysia and the results showed that there is a significant positive relationship between liquidity, firm size and profitability.

A related study conducted by Sufian and Habibullah (2009) which examined the profitability of thirtyseven (37) Bangladeshi Commercial Banks between 1997 and 2004 using a linear regression model established from their findings that firm size has a negative impact on return on average equity while the opposite is true for return on asset and net interest margins. As for the impact of the macroeconomic indicators, the gross domestic product had no significant impact on bank profitability except for inflation which has a negative relationship with Bangladeshi Banks profitability.

In Ghana, Boadi (2015) examined the influence of both internal and external factors that determine the profitability of Ghanaian Banks using the ordinary least square regression model. The results of the study indicated that there is a significant relationship between profitability, capital structure and capital to asset ratio. Lartey, Boadi, and Antwi (2013) in their study on determinants of profitability of Insurance Firms in Ghana found out that tangibility has a negative relationship with profitability. The results also established that there is a positive relationship between leverage, liquidity and profitability of insurance companies. Gyamerah and Amoah (2015) investigated the relationship between profitability and a set of bank-specific characteristics and macroeconomic factors on foreign and local Banks in Ghana. The findings suggested that cost management has a significant negative relationship with profitability while bank size and credit risk have a significant positive relationship with profitability. Krakah and Ameyaw (2010) examined the determinants of profitability of commercial banks in Ghana using the OLS regression technique. The results of their study 
show that there is a significant positive relationship between profitability, total value of assets and money supply.

\section{Methodology}

This study adopted the explanatory research approach. The study population consisted of all manufacturing companies listed on the Ghana Stock Exchange (GSE) from which a sample of five (5) companies was purposively selected. The companies were chosen due to the availability of data for the period under study. The study used secondary data from published financial statements of the selected manufacturing companies obtained from the GSE website, data on macroeconomic indicators were obtained from the Bank of Ghana (BoG) website covering the period from 2005-2015. The Panel Data methodology was employed to achieve the objective of this research. The study employed the most important factors that influence companies' profitability and that was commonly used in previous literature. The Variables and their description used in this study are listed in Table 1.

Table-1. Description of Variables and Measurements.

\begin{tabular}{l|l}
\hline Variable & Measurement \\
\hline Dependent Variable & \\
\hline Return on Asset (ROA) & Ratio of Net Income to Total Assets \\
\hline Independent Variables & \\
\hline Internal Factors & Ratio of Total Debt to Total Assets \\
\hline Leverage (LEV) & Ratio of Current Assets to Current Liabilities \\
\hline Liquidity (LIQ) & Ratio of Fixed Assets to Total Assets \\
\hline Tangibility (TAN) & Natural Log of Sales \\
\hline Firm size (FSIZE) & \\
\hline External Factors & Natural Log of GDP \\
\hline Gross Domestic Production (LNGDP) & Annual Inflation Rate \\
\hline Inflation (INFL) & Annual Treasury Bill Rate \\
\hline Interest Rate (IR) &
\end{tabular}

\subsection{Model Specification}

To test the relationship between the dependent variable (profitability) and the independent variables (both internal and external variables) as described earlier, the multivariate regression model is estimated in the following form:

$$
y_{j t}=\delta_{j}+\alpha^{l} X_{i j t}+\beta^{\prime} X_{e t}+\varepsilon_{j t}
$$

Where $j$ refers to an individual manufacturing company; $t$ refers to the year; $y_{j t}$ refers to the dependent variable (Return on Assets) and it is the observation of the manufacturing company $j$ in a particular time $t ; X_{i}$ represents the internal factors (determinants) of a manufacturing company; $X_{e}$ represents the external factors (determinants) of a manufacturing company; $\boldsymbol{\varepsilon}_{\mathrm{jt}}$ is a normally-distributed random variable disturbance term.

Extending Equation 1 to reflect the variables, as described in Table 1 the empirical model to be used in the study are formulated as follows:

$$
R O A_{j t}=\delta_{0}+\alpha_{1} L E V_{j t}+\alpha_{2} L I Q_{j t}+\alpha_{3} T_{A N}+\alpha_{4} F_{S I Z E_{j t}}+\beta_{1} L N G D P_{t}+\beta_{2} I N F L_{t}+\beta_{3} I R_{t}+\varepsilon_{j t}
$$

\subsection{Model Diagnosis}

Panel data was employed in the study which is likely to be affected by the existence of Multicollinearity, Heteroscedasticity, and Autocorrelation. The significant existence of any of this is likely to make the estimators biased making the coefficients no longer BLUE (best linear unbiased estimators) since the estimated coefficients are likely to have errors in some cases. The significance of the existence of these noises would mean that some assumptions underlying the multivariate regression model have been debased.

To test for the independence of the predictor variables, the study adopted the use of two multicollinearity statistics, which are variance inflation factors (VIF) statistics and tolerance test. Small intercorrelations among the predictor variables imply that VIF $\approx$ 1. But when the VIF $>10$, then collinearity is a problem and the model needs to be checked. The Durbin-Watson statistic was used to test if there exists autocorrelation or not. This tested for correlation between errors. It tested whether adjacent residuals are correlated, which is a violation of linear regression assumption that residuals should be independent. The Durbin-Watson Test for serial correlation assumes that the error terms $\left(\varepsilon_{i}\right)$ are stationary and normally distributed with a mean of zero 
(0). It tested the null hypothesis $\left(\mathrm{H}_{0}\right)$ that the errors are uncorrelated against the alternative hypothesis $\left(\mathrm{H}_{1}\right)$ that the errors are autocorrelated. The test statistic can range from $0-4$ and with a value of 2 meaning that the residuals are uncorrelated. A value greater than two indicates a negative correlation between adjacent residuals whereas a value below 2 indicates a positive correlation. The size of the Durbin-Watson statistic depends upon the number of predictors in the model and the number of observations. For accuracy, the exact acceptable values in Durbin and Watson (1951) original paper were used. As a rule of thumb, Field (2009) suggests that values less than 1 or greater than 3 are definitely cause for concern; however, values closer to 2 may still be problematic depending on one's sample and model. Eventually, the T-Statistic is used to evaluate the significance of estimated regression coefficients and the mean of variables. To test for the existence of heteroscedasticity, the Breusch- Pagan/Cook-Weisberg test was employed. This test involves testing the null hypothesis and that the error variances are all equal versus the alternate hypothesis that the error variances are a multiplicative function of one or more variables. A large chi-square would indicate that heteroscedasticity is present, hence the error term is a multiplicative function of the predicted values.

\section{Analysis of Empirical Results \\ 4.1. Descriptive Statistics of Variables}

The descriptive statistics of the variables are presented in Table 2 below. The descriptive statistic is based on five (5) manufacturing companies eleven (11) years dataset and which is made up of fifty (55) observations. The return on assets ratio measures how efficiently a company can convert the money used to purchase asset into net income. From the analysis, manufacturing companies in Ghana earn an average return of $13.96 \%$ on its investment in assets. The profitability of manufacturing companies is highly volatile since the standard deviation was greater than the mean. The mean for leverage is 0.6369 , which shows that manufacturing companies in Ghana employ an average of $63.7 \%$ debt capital in their operations. This is also an indication that the average manufacturing company in Ghana employs a higher ratio of debt financing to equity. The liquidity ratio revealed that on the average, the current assets of manufacturing companies in Ghana can cover their current liabilities 1.9473 times. In some literature, the ideal liquidity ratio recommended for businesses is 2 times. This shows that Ghanaian manufacturing companies are able to manage their current liabilities effectively. It was also found out that Ghanaian manufacturing companies are made of more tangible as sets than intangible assets. Averagely, the total assets of manufacturing companies in Ghana consist of $66 \%$ fixed assets. The average manufacturing company firm size in Ghana is 0.327. The size of a Firm is one of the decisive factors in the achievement of efficiency in its operations because large-scale production is considered to bring most economic results by way of lower costs and higher returns. During the period under study, the average inflation rate was $16.25 \%$ and the average interest rate was $17.48 \%$ which was relatively higher as compared to that of Ghana's neighboring countries and that of the countries Ghanaian manufacturing companies are competing with, within the same market. The data were tested for normality using ShapiroWilk test and the test indicated that data for all the variables were not normally distributed. All the results of the test were significant at $1 \%$ significance level.

\begin{tabular}{l|l|l|l|l|l|l|l|l}
\multicolumn{1}{l}{ Table-2. Descriptive Statistics of Variables. } \\
\hline Statistic & ROA & LEV & LIQ & TAN & FSIZE & LNGDP & INFL & IR \\
\hline Minimum & -0.5488 & 0.0447 & 0.4313 & 0.1750 & 0.7054 & 10.2405 & 11.21 & 9.60 \\
\hline Maximum & 3.0303 & 3.0078 & 7.6849 & 5.0743 & 1.7579 & 10.6794 & 23.90 & 25.79 \\
\hline Mean & 0.1396 & 0.6369 & 1.9473 & 0.6624 & 0.3271 & 10.4802 & 16.2482 & 17.4845 \\
\hline Std. Deviation & 0.4308 & 0.6053 & 1.6889 & 0.8169 & 0.3617 & 0.1286 & 4.4783 & 6.3058 \\
\hline Variance & 0.1860 & 0.3660 & 2.8530 & 0.6670 & 0.1310 & 0.0170 & 20.056 & 39.763 \\
\hline Skewness & 5.6410 & 2.4333 & 1.995 & 3.9910 & -0.552 & -0.3170 & 0.475 & -0.33 \\
\hline Kurtosis & 39.0670 & 7.2020 & 3.6070 & 17.6620 & 5.1880 & -0.7550 & -1.145 & -1.841 \\
\hline Shapiro-Wilk & $0.428^{*}$ & $0.730^{*}$ & $0.728^{*}$ & $0.500^{*}$ & $0.875^{*}$ & $0.947^{*}$ & $0.864^{*}$ & $0.8111^{*}$ \\
\hline Observation & 55 & 55 & 55 & 55 & 55 & 55 & 55 & 55 \\
\hline \multicolumn{2}{l}{ Source: Survey Data, 2017. NB: NB: *** significant at 1\%. }
\end{tabular}

\subsection{Correlation Matrix of Predictor Variables}

The correlation matrix as presented in Table 3 shows the level of correlation among the predictor variables used in the multivariate regression analysis. The matrix shows that in general, the correlation between the variables is not strong suggesting that there are no multicollinearity problems among predictor variables as all the correlations show values of below 0.80 (Kennedy, 2008). 
Table-3. Correlation results of covariate.

\begin{tabular}{l|l|l|l|l|l|l|l}
\hline Variable & Lev & Liq & Tan & Fsize & Lngdp & Infl & Ir \\
\hline LEV & 1.000 & & & & & & \\
\hline LIQ & -0.227 & 1.000 & & & & \\
\hline TAN & 0.259 & -0.092 & 1.000 & & & & \\
\hline FSIZE & 0.426 & 0.060 & $0.560^{* *}$ & 1.000 & & & \\
\hline LNGDP & 0.145 & 0.150 & 0.181 & 0.121 & 1.000 & \\
\hline INFL & -0.010 & -0.045 & -0.026 & -0.158 & 0.125 & 1.000 \\
\hline IR & O.095 & 0.027 & 0.019 & -0.089 & 0.425 & $0.652^{* * *}$ & 1.000 \\
\hline
\end{tabular}

\subsection{Multicollinearity Analysis}

Prior to conducting the regression analysis, the researchers tested the data to check if there is a multicollinearity problem. The two (2) major techniques used to test for multicollinearity among the predictor variables in this study are Tolerance test and Variance Inflation Factor (VIF). As opined by Menard (1995) a Tolerance value of less than 0.1 is an indication that certainly there exists a serious multicollinearity problem. Myers (1990) also suggested that a VIF value greater than 10 calls for concern. As per the results displayed in Table 4 none of the variables has a Tolerance level less than 0.1 and VIF values are well below 10. This implies that multicollinearity is not a problematic issue or concern for this study. This test has confirmed the results of the correlation matrix which suggested that there are no multicollinearity problems among the predictor variables.

Table-4. Multicollinearity Statistics: Tolerance test and Variance inflation factor (VIF).

\begin{tabular}{l|l|l}
\hline \multicolumn{2}{l}{ Table-4. Multicolinearity Statistics: Tolerance test and Variance inflation factor $(\mathrm{VIF})}$. \\
\hline LEV & Tolerance & VIF \\
\hline LIQ & 0.354 & 2.823 \\
\hline TAN & 0.921 & 1.086 \\
\hline FSIZE & 0.386 & 2.592 \\
\hline LNGDP & 0.388 & 2.579 \\
\hline INFL & 0.699 & 1.430 \\
\hline IR & 0.404 & 2.476 \\
\hline Source: Survey Data, 2017 & 0.342 & 2.923
\end{tabular}

\subsection{Multivariate Regression Analysis}

Table 5 presents the results of the predictors of profitability of selected manufacturing companies in Ghana. The multivariate regression coefficients of determinants of profitability were estimated. The estimated model is significant at the $5 \%$ level $(\mathrm{t}=9.481, \mathrm{P}=0.032, \mathrm{P}<0.05)$. The $\mathrm{R}$ Square value is 0.566 , which shows that $56.6 \%$ of the variation in the dependent variable (ROA) is explained by the predictor variables (i.e. leverage, liquidity, Tangibility, Firm size, GDP, inflation and interest rate) while $43.4 \%$ of the variation is explained by other factors which were not considered in this model. The Durbin-Watson value is 1.9545 which is closer to 2 , hence the null hypothesis $\left(\mathrm{H}_{0}\right)$ that the errors are uncorrelated is accepted. The regression assumption that the residuals are independent was not violated in this study.

According to the results in Table 5 leverage has a negative significant relationship with profitability. This shows that a high debt level will cause a reduction in a firm's profitability. A unit increase in the financial leverage of a firm will cause profitability to decrease by 0.250 units. This finding was consistent with the finding of Pratheepan (2014) which established a negative significant relationship between a firm's leverage and profitability. The results show that there is a positive significant relationship between profitability and liquidity of manufacturing firms in Ghana. A unit increase in the liquidity of manufacturing firms in Ghana will cause a 0.011 unit increase in their profitability and this finding is consistent with the findings of Maroa and Kioko (2016); Zaid et al. (2014) and Al-Jafari and Al Samman (2015) which established that liquidity has a positive significant relationship with profitability. The results also show that there is a negative but statistically insignificant relationship between tangibility and profitability. This finding is inconsistent with the findings of Pratheepan (2014) and Maroa and Kioko (2016) which established a significant negative relationship between tangibility and profitability but consistent with the findings of Al-Jafari and Al Samman (2015) which established a positive insignificant relationship between profitability (ROA) and tangibility. The results indicated that there is a significant positive relationship between firm size and profitability among manufacturing firms in Ghana. This shows that a unit increase in firm size will cause a 0.308 unit increase in profitability. Also, it is an indication that large firms are more likely to be profitable than small firms. Larger firms take advantage of their position in the market in negotiating prices of their raw materials and inputs and this leads to a reduction in the average cost of production and hence, improving the profitability. Large firms also enjoy economies. This finding is consistent with the findings of Pratheepan (2014); Al-Jafari and Al 
Samman (2015); Gyamerah and Amoah (2015) and Maroa and Kioko (2016) which established a positive significant relationship between firm size and profitability. In relation to the macroeconomic variables (i.e. GDP, inflation and interest rate), it was established that there exists a negative statistical insignificant relationship between Gross Domestic Product (GDP), inflation and profitability. This finding is consistent with the findings of Zaid et al. (2014) which came out with the findings that there exists a negative statistically insignificant relationship between GDP and Profitability, but inconsistent with the findings of Sufian and Chong (2008) which established a positive significant relationship between GDP and Profitability and a negative significant relationship between inflation and profitability. Also, it was established that there is a negative significant relationship between profitability and interest rate. A unit increase in interest rate will cause the profitability of Ghanaian firms to decrease by 0.060 units.

Table-5. Summary of Regression Results.

\begin{tabular}{|c|c|c|c|c|c|c|}
\hline \multicolumn{7}{|c|}{ Dependent Variable: Return on Assets (ROA) } \\
\hline \multirow[t]{2}{*}{ Variable } & \multicolumn{2}{|c|}{$\begin{array}{l}\text { Unstandardized } \\
\text { Coefficients }\end{array}$} & \multirow{2}{*}{$\begin{array}{l}\text { Standardised } \\
\text { Coefficients } \\
\text { Beta }\end{array}$} & \multirow[t]{2}{*}{ T-statistic } & \multirow[t]{2}{*}{ Sig. } & \\
\hline & $\beta$ & Std. Error & & & & \\
\hline Constant & 3.001 & 5.676 & & & 0.000 & \\
\hline Leverage (LEV) & $-0.250^{*}$ & 0.237 & -0.351 & -0.351 & 0.097 & \\
\hline Liquidity (LIQ) & $0.011^{* * *}$ & 0.53 & -0.043 & -0.043 & 0.001 & \\
\hline Tangibility ( TAN) & 0.037 & 0.193 & 0.07 & 0.070 & 0.230 & \\
\hline Firm size (FSIZE) & $0.308 * * *$ & 0.277 & -0.043 & -0.043 & 0.002 & \\
\hline LNGDP & -0.243 & 0.547 & -0.073 & -0.073 & 0.659 & \\
\hline Inflation (INFL) & -0.050 & 0.022 & -0.056 & -0.056 & 0.860 & \\
\hline Interest Rate (IR) & $-0.060^{* *}$ & 0.017 & -0.075 & -0.075 & 0.030 & \\
\hline Model & $\boldsymbol{R}$ & $\boldsymbol{R}^{e}$ & Adjusted R Square & $\begin{array}{l}\text { Std. Error the } \\
\text { Estimate }\end{array}$ & $\begin{array}{l}\text { Durbin- } \\
(8,55)\end{array}$ & Watson \\
\hline 1 & 0.752 & 0.566 & 0.534 & 0.432214 & 1.9545 & \\
\hline
\end{tabular}

Testing for the presence or otherwise of heteroscedasticity in the model, the Breusch-Pagan/ CookWeisberg test was employed. In this model, a large Chi-square value would indicate that heteroscedasticity is present in the model. The results of the Breusch-Pagan / Cook-Weisberg test for heteroscedasticity is presented in Table 6 below. The result indicates a relatively small chi-square. The null hypothesis $\left(\mathrm{H}_{0}\right)$ that constant variance is accepted because of the $\mathrm{P}$-value $=0.913$ and $\mathrm{P}>0.05$. This shows that the error variances are all equal. Heteroscedasticity is therefore, not present in the model, an indication that the regression model is a good fit.

Table-6. Breusch-Pagan / Cook-Weisberg test for heteroscedasticity.

\begin{tabular}{l}
\hline $\mathrm{H}_{\mathrm{o}}$ : Constant variance \\
\hline Variables: fitted values of ROA \\
\hline chi $^{2}(1)=0.10$ \\
\hline${\text { Prob }>\text { chi }^{2}=0.913}_{\text {Source: Survey Data, } 2017 .}$
\end{tabular}

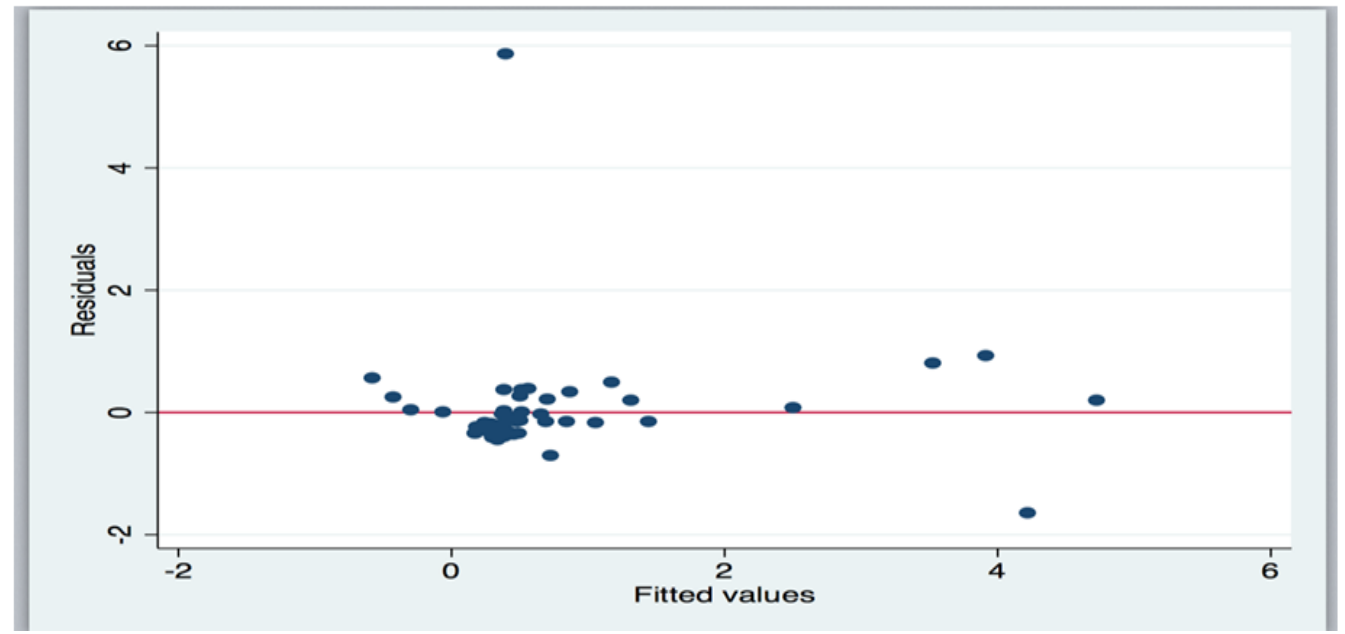

Source: Survey Data, 2017

Figure-1. Residuals versus fits plot. 
From Figure 1 above, it can be seen that the residuals are centered around zero (0) with no distinct pattern formed. The scatter is random, hence the residuals do not contradict the linear regression assumption. This is an indication that the model is a good fit.

\section{Conclusion and Recommendations}

This study seeks to examine the factors that influence the profitability of manufacturing Firms in Ghana. The study was limited to manufacturing companies that are listed on the Ghana Stock Exchange and which were in operation during the period 2005-2015. The regression results revealed that the predictor variables (i.e. leverage, interest rate, liquidity, firm size, tangibility, GDP and inflation) explained 56.6\% of the variation in the dependent variable. The empirical findings of this study suggest that leverage and interest rate have a negative significance with profitability while liquidity and firm size have a significant positive relationship with profitability. Moreover, tangibility and GDP have shown an insignificant relationship with profitability. While the study is limited to a sample of selected manufacturing companies listed on the Ghana stock exchange, the finding of this research could be generalized to companies of similar characteristics.

The findings of this study have considerable policy relevance. It could be contended that a more profitable manufacturing company will be able to introduce more products. To this end, the role of technology advancement is particularly important given that a manufacturing company with relatively more advanced technology may have a competitive advantage over the others. The continuous success of manufacturing Firms in Ghana depends on their efficiency, competitiveness and profitability. In view of the increasing competition as a result of market and trade liberalization policies, stakeholders of manufacturing companies are more inclined to find ways to obtain optimum utilization of capacities while making the best use of their resources, so that these resources are not wasted during the production process. The macroeconomic environment in Ghana plays an essential role in the survival and profitability of manufacturing companies in Ghana as evident in the empirical results. Thus, it is vital that managers of the economy keep a close eye on the implications of their policies and its impact on the manufacturing sector in their attempt to grow the economy. The findings also send a signal to all manufacturing companies in Ghana that they cannot ignore the macroeconomic indicators when strategizing to improve their profitability. Manufacturing firms in Ghana, therefore, should not only be concerned about internal policies and structures. They should take into account both the micro and macro environment when mapping out strategies to improve on their profitability.

Future research on this subject should consider the other equally important sectors of the economy. It should also include more variables such as taxation and regulation indicators, exchange rates, management quality and corporate governance to make the results and findings more robust. In terms of methodology, a statistical cost accounting and frontier techniques can also be employed.

\section{References}

Al-Jafari, M. K., \& Al Samman, H. (2015). Determinants of profitability: Evidence from industrial companies listed on Muscat Securities Market. Review of European Studies, 7(11), 303-311.

Aparna, K. (2015). Determinants of profitability-a firm level study of steel authority of India Limited (SAIL). Journal of Business Management E Social Sciences Research (JBMESSR), 4(12), 1-4.

Bashar, S. M., \& Islam, M. I. (2014). Determinants of profitability in the pharmaceutical industry of Bangladesh. Journal of SUB, 5(1), 56-76.

Boadi, I. (2015). Profitability determinants of the Ghanaian banking sector in ongoing wave of consolidation. International Journal of Business and Management, 10(12), 1-11.

Durbin, J., \& Watson, G. S. (1951). Testing for serial correlation in least squares regression. Biometrics, 38(1/2), $159-177$.

Field, A. (2009). Discovering statistics using SPSS (3rd ed.). Thousand Oaks: SAGE Publications.

Ghana Statistical Service. (2017). Statistics for development and progress. Retrieved, from provisional 2016 annual gross domestic product.

Gyamerah, A. I., \& Amoah, B. (2015). Determinants of bank profitability in Ghana. International Journal of Accounting and Financial Reporting, 5(1), 173-187.

Kennedy, P. (2008). A guide to econometrics. Malden, Mass: Blackwell Publishing.

Krakah, K. A., \& Ameyaw, A. (2010). The determinants of bank's profitability in Ghana, The case of merchant bank Ghana Limited (MBG) and Ghana Commercial Bank (GCB). Thèse, Institut Blekinge Technology School of Management.

Lartey, C. V., Boadi, E. K., \& Antwi, S. (2013). Determinants of profitability of insurance firms in Ghana. International Journal of Business and Social Research, 3(3), 43-50.

Maroa, G., \& Kioko, W. (2016). Determinants of profitability of agricultural firms listed at the Nairobi Securities Exchange, Kenya. International Journal of Economics, Commerce and Management, 4(9), 225-235.

Menard, S. (1995). Applied logistic regression analysis. Sage University paper series on quantitative applications in the social sciences (pp. 70-106). Thousand Oaks, CA: Sage.

Myers, R. (1990). Classical and modern regression with applications (2nd ed.). Boston, MA: Duxbury.

Pratheepan, T. (2014). A panel data analysis of profitability determinants: Empirical results from Sri Lankan manufacturing companies. International Journal of Economics, Commerce and Management, 2(12), 1-9.

Prempeh, K. B., Sekyere, A. M., \& Asare, E. N. (2016). The effect of debt policy on firms' performance: Empirical evidence from listed manufacturing companies on the Ghana stock exchange. IOSR Journal of Economics and Finance, 7(4), $1-8$. 
Sivathaasan, N., Tharanika, R., Sinthuja, M., \& Hanitha, V. (2013). Factors determining profitability: A study of selected manufacturing companies listed on Colombo Stock Exchange in Sri Lanka. European Journal of Business and Management, 5(27), 99-108.

Sufian, F., \& Chong, R. R. (2008). Determinants of bank profitability in a developing economy: empirical evidence from the Philippines. Asian Academy of Management Journal of Accounting \& Finance, 4(2), 91-112.

Sufian, F., \& Habibullah, M. S. (2009). Determinants of bank profitability in a developing economy: Empirical evidence from Bangladesh. Journal of Business Economics and Management, 1O(3), 207-217.

Tobi, A., Osidero, T., \& Kareem, P. (2016). Empirics of liquidity and profitability in the Nigerian manufacturing sector. International Journal of Economics, Commerce and Management, 4(9), 480-492.

Yazdanfar, D. (2013). Profitability determinants among micro firms: Evidence from Swedish data. International Journal of Managerial Finance, 9(2), 151-160.

Zaid, M. N., Wan Muhd, F. I., \& Zulqernain, S. N. (2014). The determinants of profitability: Evidence from Malaysian construction companies. Paper presented at the 5th Asia-Pacific Business Research Conference. Kuala Lumpur: Minister of Works Malaysia. 